\title{
New Permo-Carboniferous geochemical data from central Thailand: implication for a volcanic arc model
}

\author{
Wladyslaw Altermann ${ }^{1}$ \\ University of Stellenbosch, Stellenbosch, South Africa
}

(Received and accepted March 14, 1991)

\begin{abstract}
Altermann, W., 1991.New Permo-Carboniferous geochemical data from central Thailand: implication for a volcanic arc model. Palaeogeogr., Palaeoclimatol., Palaeoecol., 87: 191-210.

Current ideas and models of geotectonic reconstructions of Southeast Asia are reviewed and new data on Late Carboniferous through Middle Permian tuffites and sills from central Thailand are presented in the light of the problems of Southeast Asian palaeogeography. The volcanic rocks of quartz-keratophyric to spilitic composition are associated with platform carbonates and deep basin sediments. Their geochemistry and the character of the accompanying sediments suggest the existence of a Late Palacozoic volcanic arc separating a subduction zone in the west from a back arc basin to the east. The geotectonic frame of Southeast Asia is explained in terms of repeated accretion of volcanic arcs by the Late Palaeozoic subduction zone along the northern Tethys margin.
\end{abstract}

\section{Introduction:}

Southeast Asia is generally accepted to comprise three different tectonic blocks: In the west, the "Shan Thai Craton"; in the east the "Indosinia Block" or "Indochina Block" occupying east Thailand, Kampuchea, Laos, and Vietnam; and the "South China Block" north of "Indosinia". Geochemical data discussed in the present paper add some new information on the plate-tectonic puzzle of Southeast Asia. A strong indication for the existence of a volcanic arc during the Late Palaeozoic is given by the geochemistry of the Carboniferous and Permian volcanic rocks.

\section{Geological background:}

In the discussion of the palaeogeography of Southeast Asia, questions that always emerge as a subject of controversial debate are: Which parts of Southeast Asia are derived from the dispersing Gondwana continent and when did the various

\footnotetext{
${ }^{1}$ Present address: Goethering 27a, D-8504 Stein, Germany
}

Tethys realms, which separated the different fragments of present Southeast Asia, become extinct?

According to Gatinsky and Hutchinson (1984) South China and Indosinia acted as a single block since the Devonian or Early Carboniferous. This is strongly supported by palaeontological and stratigraphical evidence and will not be further discussed in the present paper.

However, profound controversies exist as to the timing of the closure of the remaining branches of the Tethys.

The numerous approaches to resolve this question culminated essentially in two opposing theories:

- The widely accepted point of view (Sengör, 1985) attempts to explain the geotectonic evolution of Southeast Asia as a result of the collision of Gondwana-derived microplates with the "Indosinia Block". The "Shan Thai Craton" or the "Cimmerian Continent" of Sengör (1985) rifted away from Gondwana in the Carboniferous or Permian and drifted towards the north during Permian and Triassic times. While destroying the "Palaeotethys" in the north, it opened the "Neotethys" 
behind it. This "Craton" in Southeast Asia comprises the Shan-Plateau, western Thailand, Burma, western Peninsular Malaysia and northern Sumatra. The collision with Indosinia occurred approximately at the Triassic/Jurassic boundary (Sengör, 1985). The welding suture between both continental blocks is seen in the Nan-Uttaradit ultramafic belt in north Thailand and in the Bentong-Raub Zone in Malaysia.

--Helmcke $(1983,1985,1986)$ developed an alternative model for the geotectonic evolution of Southeast Asia. This model is based on the discovery of Lower Carboniferous to Upper Permian pelagic, flysch, and molasse sediments in the Petchabun Fold and Thrust Belt in central Thailand. In this concept, Southeast Asia represents a part of a huge Variscan Cordilleran-type orogenic belt and the "Palaeotethys" becomes a marginal basin which closed in the pre-Middle Permian. Following this concept, the "Shan Thai Craton" therefore should rather be a part of a volcanic arc and not a part of the Upper Palaeozoic Gondwana.

Palaeomagnetic, palaeontological, and sedimentological data seem to support Sengör's (1985) widely accepted concept, but when more closely examined, these data appear ambiguous. Sedimentological and geochemical data as discussed in the present paper rather support Helmke's (1985) theory.

\section{Review}

Five different types of arguments dominate the discussion namely:

Palaeomagnetic, palaeontological, sedimentological, tectonic and volcanic. In the following paragraphs these arguments are reviewed with special attention to the discussion of volcanic rocks.

\section{Palaeomagnetic arguments}

In most palaeogeographic reconstructions Southeast Asia is presented as a part of the PermoCarboniferous Gondwanaland. However, on the Geological Map of Gondwana (De Witt et al., 1988) it appears north of the "Prototethys" in the upper right inset of the map, but as a part of the Gondwana shelf in the lower left inset, which depicts the alternative reconstruction of Gondwanaland $150 \mathrm{Ma}$ ago. This uncertainty reflects the little reliable palaeomagnetic data.

Bunopas (1981) placed the "Shan Thai Craton" at $13^{\circ} \mathrm{S}$ in the Carboniferous and $19^{\circ} \mathrm{S}$ in the Permian. He suggested a clockwise rotation of more than $180^{\circ}$ for the "Shan Thai Craton", while crossing the Palaeotethys. The data are based on samples from the Phuket and Kaeng Krachan Groups and from the Permian limestone overlying the pebbly mudstones. The Kaeng Krachan and Phuket Groups samples are assumed to be of Carboniferous age although these groups range from Late Devonian to Early Permian (Burton, 1986).

McElhinny et al. (1974) treated the entire Malay Peninsula as a single block, which they placed at $15^{\circ} \mathrm{N}$ during the Late Palaeozoic. These data have been criticized by several authors as being due to remagnetization by younger plutonic intrusions and not showing the true Palaeozoic position.

Data even more contrary to the possible Gondwana provenance of the "Shan Thai Craton" were presented by Haile (1980), who reported a palaeolatitude of $43^{\circ} \mathrm{N}$ for the Ordovician and Silurian Setul Limestones from the Langkawi Islands, northwest Malaysia. Haile (1980) argued that his samples were not influenced by remagnetization; however, his results were later criticized, based on palaeobiogeographic arguments, as being highly unreliable (Metcalfe, 1986).

\section{Palaeontological arguments}

The palaeobiogeographic problems of the "Palaeotethys" were widely discussed by Dickins (1985) and Metcalfe (1986).

For example the Permian brachiopods from western Thailand and Malaysia (Shan Thai) were described by Grant (1976) as living under tropical conditions and as rather cool-water fauna, with some palaeotropical affinities by Waterhouse (1982).

Rao (1988), investigated the palaeotemperatures as indicated by oxygen and carbon isotopes of productid brachiopods from the Permian Chuping Limestone in Malaysia and reported an estimated range of $2^{\circ}$ to $13^{\circ} \mathrm{C}$ and "cool-temperate (to ?sub- 
polare) conditions" from the primary sedimentary and diagenetic features (Rao, 1988, pp. 165-166). For the Permian Summalayang Limestone, Rao (1988) reported a temperate palaeoclimate reflected by Mg-calcite mineralogy in cements and in the Tethyan fusulinid fauna. For the Chuping Limestone he suggested that they have equilibrated with melt waters because of the presence of detrital grains which he assumed to have been dropped from ice-rafting. Even if this assumption is correct, equilibration with phreatic or/and vadose waters would be much more probable. For the Triassic Kodiang Limestone Rao (1988) reported a tropical palaeoclimate. However, in his discussion of evaporite occurrences he seemed to confuse tropical and arid conditions. Most importantly, palaeotemperatures of marine waters do not necessarily indicate palaeolatitudes. In the Recent, cold Antarctic currents influence the climate and marine fauna along the western coasts of Africa or South America as far north as Namibia, northern Chile and Peru. None of the palaeomagnetic data discussed above allow for subpolar palaeolatitudes of the Lower Permian "Shan Thai Craton". Therefore, such currents must be assumed even for the palaeolatitudes presented by Bunopas (1981).

The findings of Glossopteris in western Thailand (Shan Thai) were identified as Walchia piniformis after a closer examination (Bunopas and Vella, 1984). Walchia piniformis was also reported from the Lower Permian in north Thailand by Baum et al. (1970). This genus is unknown in Cathaysian and Gondwanian floral assemblages. Typically Euramerican faunas were described from eastern Peninsular Malaysia (Indosinia) by Metcalfe (1983).

Ingavat-Helmcke and Helmcke (1986), certified Eurasian and Arctic affinities to the Lower Permian foraminiferas from Thailand (Indosinia and Shan Thai) and Buffetaut and Ingavat (1985) identified Triassic land vertebrates in Thailand (Indosinia) as of Laurasian provenance.

Lower Permian warm-water corals as known from Thailand, Laos, Yunnan, and from the Maping Limestone in south China, were reported as far south as Sumatra (Djambi) by Fontaine (1986).

The list of further palaeontological criteria against the Upper Palaeozoic Gondwana prove- nance of the "Shan Thai Craton" could be extended. Apparently there is much better evidence for the Early Palaeozoic relationship of the "Shan Thai Craton" to Gondwana (Burrett and Stait, 1986). This evidence will not be discussed here, since the paper deals only with the Upper Palaeozoic. It should be mentioned however, that Burrett and Stait (1986) discussed biogeographic and taxonomic similarities of Upper Cambrian and Ordovician faunas of Australia and the Shan Thai and concluded that the break-up of Shan Thai from Gondwana occurred at the latest during the Early Carboniferous. By Early Permian times this microcontinent reached sub-tropical palaeolatitudes and eventually collided with Indochina in the Triassic.

\section{Sedimentological arguments}

The sedimentological data present an even more confusing picture. Stöcklin (1984) noted the lack of Permo-Triassic Tethyan truly oceanic sediments and true ophiolites in the so-called "Palaeotethys" realm. However, Sengör's (1985) "Palaeo-" and "Neotethys" concept has been criticized by Tozer (1989) as being not strictly chronological or geographic but rather a genetic interpretation.

Helmcke (1983, 1995) described the occurrence of a Permian orogenic sedimentary suite, consisting of pelagic, flysch, and molasse sediments in central Thailand (Petchabun Fold and Thrust Belt). These sediments range from the lowermost Early Permian (Asselian) to the lowest Late Permian (Midian) and become generally younger towards the east, the oldest pelagic strata being located in the western and the youngest molasse strata in the eastern parts of the Petchabun Fold and Thrust Belt. In the $T_{1}$-intervals (lowest Bouma sequence) of the flysch sediments Murgabian (uppermost Middle Permian) foraminifera (Pseudodoliolina sp.) were found and ammonites (Agathiceras suessi) were collected from the pelagic shales intercalated with the turbidites (Ingavat-Helmcke and Helmcke, pers. comm., 1987). The entire suite is isoclinally folded and thrust towards the east.

No truly oceanic, but only marginal marine, post-orogenic sediments are known from the Late 
Permian of central Thailand (Wielchowsky and Young, 1985; Altermann, 1989).

Mudcracks and brachiopod pavements inconsistent with turbiditic deposition were described from the so-called Lampang-Hong Hoi Triassic "flysch" from northern Thailand (Helmcke, 1986). These obviously marginal marine sediments were often considered to represent the orogenic sediments of the Triassic Tethys Ocean in northern Thailand (Sengör, 1985). Metcalfe (1989) reported a Triassic carbonate platform with adjacent deep water basin containing pelagic cherts and turbiditic rhythmites from the Shan Thai part of Malaysia and Sumatra and suggested their correlation with the Lampang "flysch". However, turbiditic deposits can also originate in fault-controlled extensional basins, as described for the Triassic of northeastern Thailand (Cooper et al., 1989).

The Upper Palaeozoic pebbly mudstones of western Thailand and Malaysia were discussed as continental margin deposits (Garson et al., 1975; Altermann, 1986, 1987) or flysch-like sediments by Burton (1986) and as glaciomarine Gondwana sediments (Stauffer, 1983; Stauffer and Lee, 1986, 1987). In his detailed discussion of these rocks, Burton (1986) clearly showed that the beginning of their deposition in the Middle Devonian predates the Gondwana tillites and that the time range of their deposition from Middle Devonian to Early Permian coincides only in part with the Late Palaeozoic Gondwana glaciation. Furthermore, Burton (1986) argued that the regional extent of the pebbly mudstone outcrops from Sumatra to Burma, some $2100 \mathrm{~km}$ in strike but only about $180 \mathrm{~km}$ in maximum width, contends against their continental glacial origin.

\section{Structural arguments}

The strongest arguments in the discussion of the palaeogeography and folding events of Southeast Asia are given by the tectonic overprint of the region.

The deformation of the Triassic rocks in Thailand and Malaysia is generally from a single folding phase. Upright, large-wavelength folds prevail and are certainly not typical of a continental-collision orogeny. Is this the Indosinian Late Triassic to
Early Jurassic folding or is this folding related to the "alpine" overprint? Cooper et al. (1989) demonstrated the development of large extensional, half-graben basins in the Late Triassic of northeastern Thailand. The extension tectonics followed the Late Permian or Early Triassic collision of Shan Thai and Indosinia. These basins were folded only in the Late Cretaceous-Early Tertiary.

Unlike the Mesozoic, the Palaeozoic is deformed by complex polyphase folding. East-vergent, isoclinal folds prevail and steeply plunging fold axes are common. The youngest isoclinally folded strata are lowest Upper Permian (Midian). The Midian is generally followed by an angular unconformity and the lowest Triassic is generally missing (ESCAP, 1988). Thus any important continental collision must have occurred before the first preserved Triassic sediments were deposited and before the uppermost Permian and the lowest Triassic were eroded subsequently to post-collisional uplift (Helmcke, 1983, 1985; Altermann, 1989). The collision was most probably contemporaneous with the deposition of flysch sediments of the Petchabun Fold and Thrust Belt, i.e. Middle Permian (Helmcke, 1985).

These apparent problems in the palaeogeographic reconstruction described above, led Metcalfe (1986) to place the collision between his Sibumasu Block (Shan Thai) and his "Manabor Block" (east Malaya, Natuna and southwest Borneo) somewhere between Early Carboniferous and Late Triassic.

\section{Volcanism}

The Palaeozoic volcanic rocks in Thailand are important in discussions of the plate tectonic history of Southeast Asia.

In their overview of Palaeozoic to Mesozoic volcanic belts of northern Thailand, Bunopas and Vella (1978) postulated a stationary volcanic arc (Silurian to Mesozoic) located between Chiang Mai and Loei. While the western outline of these volcanic belts remained stable through time, their eastern border migrated progressively eastwards. The authors related these volcanic belts to the 
westward subduction of oceanic crust beneath the "Shan Thai Craton".

Mitchell (1977) concluded from his work on the granitic provinces in Southeast Asia that the subduction must have been E-dipping.

Macdonald and Barr (1978) described the Late Carboniferous volcanic arc between Chiang Rai and Chiang Mai and they concluded, that these volcanics are of tholeiitic origin similar to islandarc low potassium tholeiites.

Barr et al. (1985) described apparently Permian volcanics from the San Kampaeng area (ca. $25 \mathrm{~km}$ $\mathrm{E}$ of Chiang Mai). They suggested that the whole "Late Carboniferous" arc is Permian. The rocks were characterized on the basis of immobile trace elements as having a continental tholeiitic affinity. High $\mathrm{TiO}_{2}(2-3 \%), \mathrm{Nb} / \mathrm{Y}$ less than 1 , high $\mathrm{Ti} / \mathrm{Y}$ ratios (600-700) and high zirconium average (166 ppm), are most characteristic for these rocks and consistent with those previously reported from the surface outcrops of the southern part of the Late Carboniferous volcanic arc. The authors interpreted the belt as having no evidence for a palaeosuture. They believed it more likely to represent intraplate rift volcanism, located west of the Permian subduction zone.

The Nan-Uttaradit "ophiolites" which lie east of the Permian or Late Carboniferous belt described above, were investigated by Macdonald and Barr (1984). Metagabbros, epidote amphibolites, metabasalts and ultramafic rocks, which elsewhere in the literature are regarded as representing true ophiolites, were described as having a close affinity with a volcanic arc setting rather than being MORB. A close relationship to calc-alkali basalts was stressed.

Crossite-bearing blueschists associated with the mafic-ultramafic rocks were first described by Macdonald et al. (1985).

Barr and Macdonald (1987), identified the NanUttaradit Belt as Type II ophiolites (Beccaluva et al., 1979), formed by spreading processes above a subduction zone, and reported a K/Ar metamorphic age of $269 \pm 12 \mathrm{Ma}$ for the crossite schists.

Damm and Helmcke (1985) also investigated the Nan-Uttaradit Belt. Their geochemical results generally confirm those of Macdonald and Barr (1984). Also, for the first time, radiometric ages were obtained from these mafic-ultramafic rocks. The $\mathrm{K} / \mathrm{Ar}$ ages of $344 \pm 22 \mathrm{Ma}$ were interpreted as the age of the Variscan metamorphic event, i.e., the minimum age of these rocks (Damm and Helmcke, 1985).

Spilitic pillow lavas were described from southeastern Thailand, (Sra Kaeo Province) where, according to Bunopas (1981), they are unconformably overlain by limestone of Late Permian age. They were regarded as the southern continuation of the Nan-Uttaradit Belt.

Upper Triassic to Lower Cretaceous volcanics in northern Thailand were described by Bunopas (1981) and Hahn (1976) as alkali-rhyolites, which represent the extrusive counterpart of the S-type granites, widespread in Southeast Asia.

\section{New investigations}

\section{Sample localities and analytical method}

In Fig. 1 the area sampled is marked by wavy lines signature. The sample localities are given in Table 1. Some of the samples are from the Petchabun Fold and Thrust Belt (all samples from the Lom Sak-Chum Phae road, the east of Petchabun samples, the north of Loei samples, and the Huai Nam Duk sample). Other samples (vicinity of Nong Pai) are from the western carbonate platform bordering the fold belt (Altermann, 1989).

After microscopic examination, the least weathered samples and those containing the smallest amounts of sedimentary carbonate were chosen for analysis. Approximately one kilogram of each sample was crushed in a jaw crusher and processed through a disk mill. Subsequently, each sample was passed through a sample divider and milled in an agate planet mill. The major elements have been determined according to the Norrish fusiondisk technique. Trace elements were measured on powder pellets after additional processing of the samples through an agate micronising mill. The analyses were done using a Philips-XRF-spectrometer and international standards in the Institute of Mineralogy at the Freie Universität Berlin (courtesy Prof. L.J.G. Schermerhorn). 


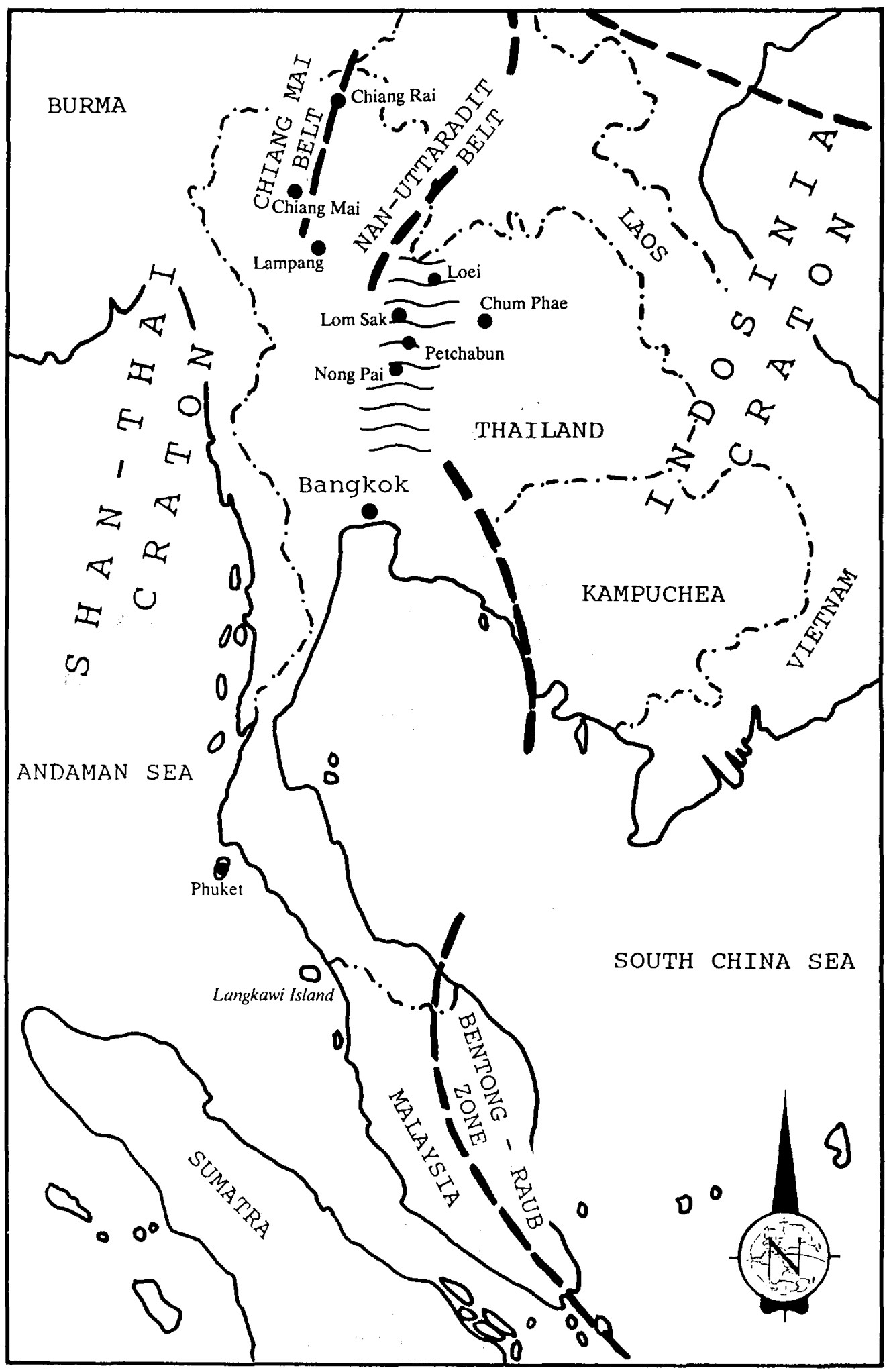

Fig. 1. Outline map of Southeast Asia showing the Shan Thai and Indosinia blocks. Wavy signature covers the working area. 


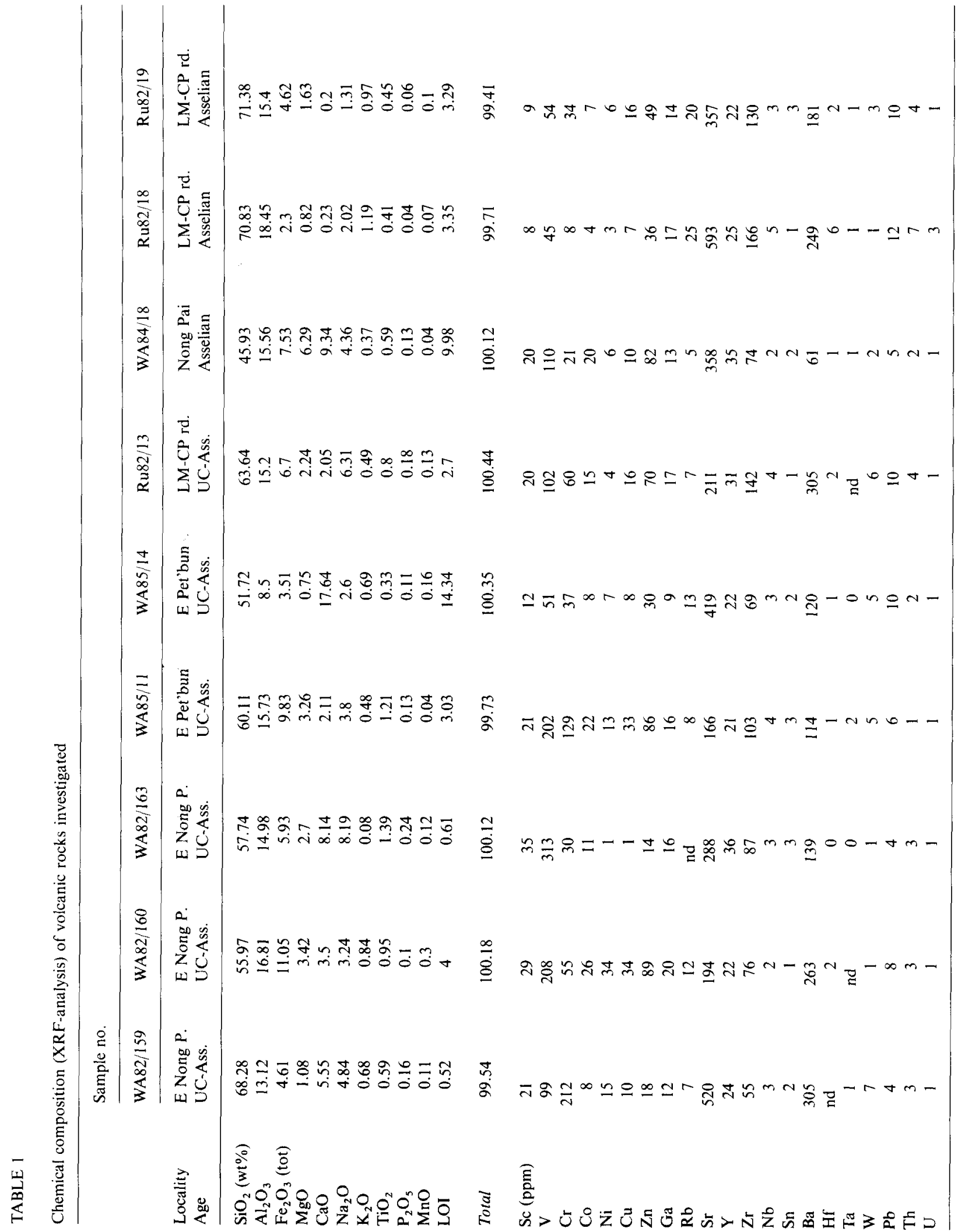




\section{Sedimentary environment and associated volcanics}

The volcanic rocks discussed in the present paper are found in two different sedimentary settings:

(1) Tuffs and tuffites are intercalated with shallow marine carbonates bordering the Permian orogenic realm to the west (Altermann, 1989).

(2) Within the pelagic facies of the Permian Petchabun Fold and Thrust Belt, allodapic (turbiditic) tuffites and sills are found folded with the strata (Winkel et al., 1983).

- The first setting is interpreted as a platform or ramp lasting from the Moscovian to the lowest Upper Permian (Midian) ages, on which the volcanic rocks were deposited as proximal tuffs. They are intercalated with subtidal to intertidal shelf carbonates of chiefly Late Carboniferous to Asselian (earliest Permian) age. However, on parts of this platform strongly weathered, felsic tuffites overlain by Kubergandian to Murgabian (middle and uppermost Middle Permian) limestones (coral boundstones of small patch reefs) have been found. These are rich in K-feldspar and plagioclase, and quartz grains exhibiting resorptive rims. They contain glass shards with fluidal plagioclase texture and are also rich in Fe-oxide grains. These strongly weathered tuffites are not further discussed in this paper.

- The second setting is characterized by the pelagites of the Petchabun Fold and Thrust Belt which predate the Murgabian flysch sedimentation and the E-vergent isoclinal folding and thrusting of the fold belt (Helmcke, 1982, 1985). The age of these volcanic rocks, obtained from foraminifera intraclasts in the interbedded allodaphic limestones, ranges from the Asselian through the Murgabian. Though the foraminifera were found in secondary deposits, the abundance of slightly abraded foraminifera bioclasts, their uniformity, the absence of other, younger species, as well as regional constraints such as possible source areas on the platform (see above) show that they are contemporary.

Parts of the pelagic sediments of the Petchabun Fold and Thrust Belt show refolding due to a later deformational event, with steeply plunging fold axes $\left(30^{\circ}-60^{\circ}\right)$, two schistosity directions and lowgrade metamorphism. In such regions, tuffites are also found, but because of the lack of fossils, their age is estimated, using regional lithologic correlations, as Late Carboniferous to Asselian. The sills within the pelagic strata are assumed to be at least of Murgabian age because their intrusion predates the Murgabian folding. Sample Ru82/51 is from a sill folded within the Bolorian (lowest Middle Permian) pelagic strata of the Petchabun Fold and Thrust Belt i.e. it must be of Middle Permian (Bolorian to Murgabian) age. WA82/163, is from a sill folded within the Upper Carboniferous to Asselian pelagic facies of the Petchabun Fold and Thrust Belt and therefore can be at most of Late Carboniferous age.

\section{Petrography}

In thin section all tuffites contain various amounts of sedimentary carbonate. Quartz and chert intraclasts are common. Altered biotite is rare. The matrix comprises either carbonate, quartz or clay. The volcanic shards and grains have a glass matrix with micro-trachytic, microporphyritic or aphanitic feldspar textures and in some samples, there are vesicles containing a very fine crystalline quartz. In most of the samples the feldspars are albite and rarely oligoclase. In some samples zonation of albite rims around oligoclase centers is common. Epidote replacing the feldspar and rare clinopyroxene have also been found and the plagioclase is often saussuritized. Clusters of goethite, hematite and pyrite are common. In sample WA85/14 two different kinds of magmatic clasts were distinguished. One has trachytic texture with small albite crystals in a recrystallized glass matrix, the other, granoblastic texture with quartz and plagioclase $\left(\mathrm{An}_{38}\right)$ intergrown with rare muscovite. K-feldspar grains are also present in this sample.

Sample Ru82/51 is from a sill folded within the Bolorian pelagic strata of the Petchabun Fold and Thrust Belt. In thin section, an aphanitic matrix of quartz and chlorite is seen with up to $6 \mathrm{~mm}$ large idiomorphic crystals of chloritized and sericitized plagioclase, together with idiomorphic biotite, which is also chloritized and rich in opaque oreminerals. Quartz is present in vesicles and in small, porphyroblastic crystals between acicular chlorite and sericite. Hematite is also present in the matrix. 
WA82/163, from a sill folded within the pelagic facies of the Petchabun Fold and Thrust Belt has a doleritic texture of plagioclase, rare K-feldspar, abundant epidote and common sphene. The epidote occurs in two generations, first as crystals within the plagioclase texture and replacing feldspar and secondly in clusters intergrown with sphene. Rare crystals of pale yellow, Fe-poor biotite and some chlorite also occur.

Following thin section examination, the rocks were classified as quartz-keratophyres sensu Schermerhorn (1973) to spilite sensu Amstutz (1974).

\section{Geochemistry}

In Table 1, the results of the major- and traceelement XRF-analyses are given.

In the $\mathrm{SiO}_{2}-\mathrm{Zr} / \mathrm{TiO}_{2}$ diagram of Winchester and Floyd (1977), fig. 2a, the samples plot in the basalt, andesite and rhyodacite-dacite fields. Similar results were obtained on the $\mathrm{SiO}_{2}-\mathrm{Nb} / \mathrm{Y}$ plot (Fig. 2b). If these samples were corrected for sedimentary contamination, only the $\mathrm{SiO}_{2}$ values would change significantly in some samples on these diagrams so that they would plot in a different field. This behavior is reflected by a fairly negative correlation of $\mathrm{CaO}$ against $\mathrm{SiO}_{2}$ i.e. the $\mathrm{CaO}$ content generally decreases with increasing $\mathrm{SiO}_{2}$ (not shown).

Results similar to those shown in Fig. 2, were obtained using $\mathrm{Zr} / \mathrm{TiO}_{2}$ versus $\mathrm{Nb} / \mathrm{Y}, \mathrm{Ga} / \mathrm{Sc}$ versus $\mathrm{Nb} / \mathrm{Y}$, and $\mathrm{Zr} / \mathrm{TiO}_{2}$ versus $\mathrm{Ga}$ plots of Winchester and Floyd (1977), although a slight shift towards the felsic end-member, and a concentration of the samples in the andesite field can be seen on the $\mathrm{Zr} / \mathrm{TiO}_{2}-\mathrm{Nb} / \mathrm{Y}$ and $\mathrm{Ga} / \mathrm{Sc}-\mathrm{Nb} / \mathrm{Y}$ plots (Fig. 3). Of importance is that when not using $\mathrm{SiO}_{2}$ as a discriminatory element, the oldest samples plot on average as the most basic members of the rocks under investigation.

In the TAS-diagram as proposed by Zanettin (1984), the samples plot in the basaltic-andesite, andesite, dacite and trachyandesite fields. The Hawaii composition line (Macdonald and Katsura, 1964) is added to the diagram to differentiate alkalic and tholeiitic magmas and the volcanic rocks investigated appear mainly tholeiitic (Fig. 4).
This is obviously influenced by the contamination with sediment which "artificially" lowers the $\mathrm{K}_{2} \mathrm{O}$ and $\mathrm{Na}_{2} \mathrm{O}$ contents and perhaps by the mobility of the alkali elements. Because of this contamination the $\mathrm{SiO}_{2}$ values seem incorrect for some samples when compared with the results in Fig. 3.

On the AFM diagram (Fig. 5) the samples plot mainly in the calc-alkaline field and show the typical calc-alkaline trend, plotting approximately normal to the $\mathrm{MgO}-\mathrm{FeO}^{*}$ limb of the AFMtriangle (Miyashiro, 1974). In the $\mathrm{FeO}^{*}$ vs. $\mathrm{FeO}^{*} /$ $\mathrm{MgO}$ diagram (Fig. 6) the oldest samples appear tholeiitic whereas all the other rocks, with one exception, plot as calc-alkaline. Using the immobile elements vanadium and chromium (Fig. 7a), one of the Upper Carboniferous to Asselian samples plots in the exclusively tholeiitic field. The rest plot in a mixed $\mathrm{TH}-\mathrm{CA}$ or even exclusively calcalkaline field. Similar behavior can be seen on the $\mathrm{SiO}_{2}$ versus chromium plot in Fig. $7 \mathrm{~b}$ (Miyashiro and Shido, 1975).

On the V/Ti plot (not shown) the rocks investigated appear mainly as of the calc-alkali suite but overlap partly with the arc tholeiite field and with MORB (Shervais, 1982). Again, only three of the oldest samples could be classified as MORB, if not their $\mathrm{SiO}_{2}$ content, which is generally too high for basalts. The same problem arises when plotting Hf, Th, and Ta in the diagram of Wood (1980), where the rocks plot between the calc-alkaline destructive margin basalt and alkaline within plate basalt fields (not shown).

As for the magma provenance, no evidence could be found for oceanic (MORB) volcanism in the area under investigation in Thailand. A strong indication for continental magma is indicated by element fractionation patterns in Fig. 8, in which the rocks from Thailand are plotted normalized to the primordial mantle (Schermerhorn, pers. comm.). The enrichment of incompatible elements is shown. Also the $\mathrm{Nb}, \mathrm{P}, \mathrm{Ti}, \mathrm{Zr}, \mathrm{Hf}$ are enriched, while the compatible elements are depleted. The fractionation patterns of the Lower Permian samples from Loei and of the samples from the Petchabun Fold and Thrust Belt and Nong Pai to the south, follow the same trend; they are thus cogenetic.

When compared to the Permian volcanic rocks 

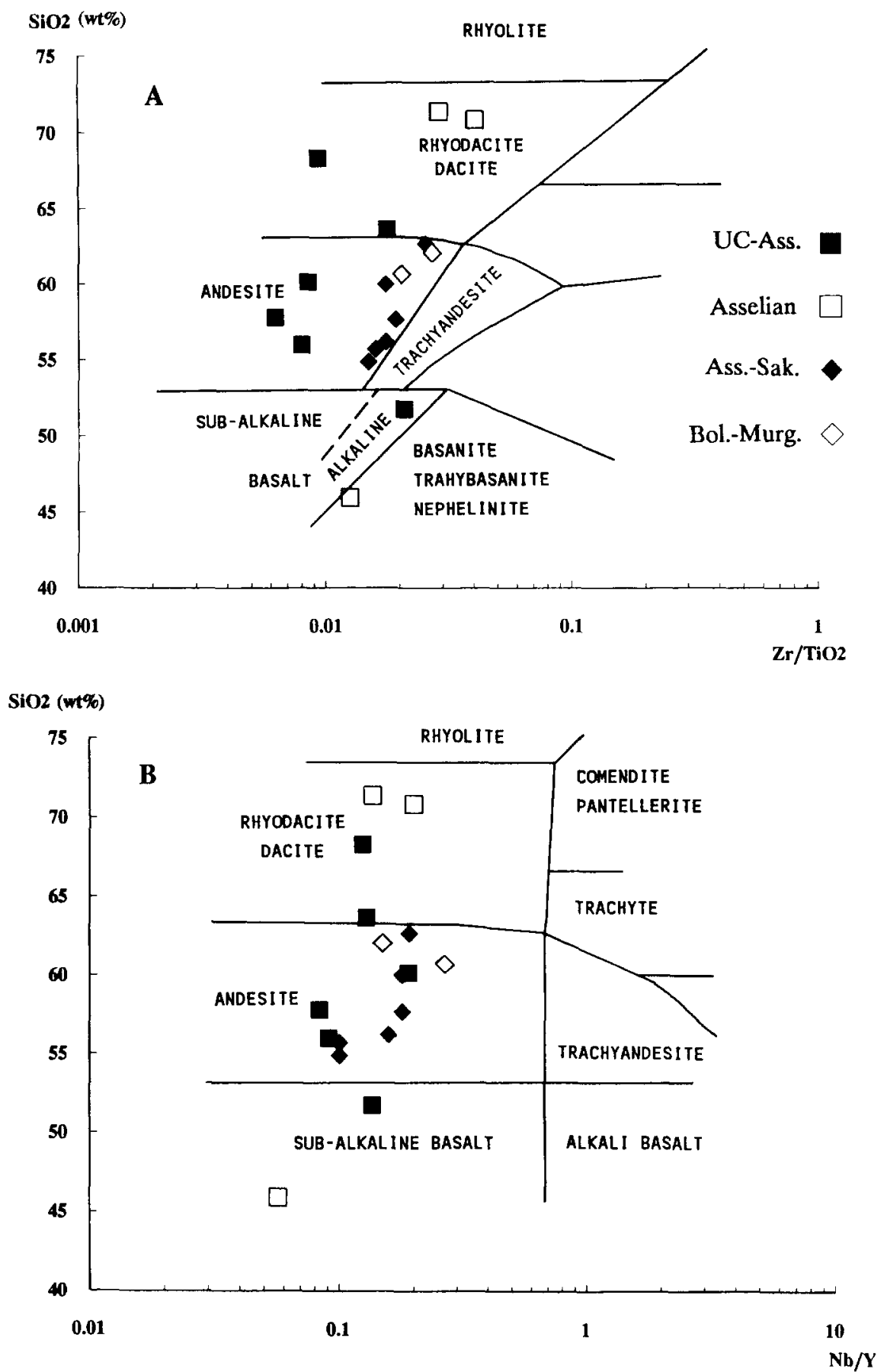

Fig. 2. Classification of the Permo-Carboniferous volcanic rocks of central Thailand using $\mathrm{SiO}_{2}$ as discrimination element (Winchester and Floyd, 1977). The symbols remain identical in all following diagrams.

described by Barr et al. (1985) from the Chiang Mai-Chiang Rai Belt, the volcanic rocks from central Thailand exhibit significantly lower $\mathrm{TiO}_{2}$ content $(0.72 \%)$, and a lower $\mathrm{Ti} / \mathrm{Y}$ ratio (between
90 and 350). The lower $\mathrm{TiO}_{2}$ content can be explained by their mainly tuffitic origin and may be due to some relative "dilution" by sediment as already discussed above. The same might be valid 
for the somewhat lower, but still similar average zirconium content (122 ppm). The $\mathrm{Nb} / \mathrm{Y}$ ratio is always much lower than 1, as in the Chiang MaiChiang Rai Belt (Barr et al., 1985).

\section{Discussion}

Taking into consideration published data as well as new information presented, the geochemical characteristics of the volcanics from central Thailand strongly suggest a volcanic arc setting for these rocks.

Three characteristics of the Palaeozoic volcanic rocks in central Thailand are significant and support the presence of a volcanic island arc in the Late Carboniferous and Permian of Thailand:

(1) The volcanism is of an earlier date. It predates the folding and the sedimentation of the flysch in the Petchabun Fold and Thrust Belt.
(2) The rocks show a distinct development from tholeiitic to calc-alkaline series (compare Bunopas, 1981; Macdonald and Barr, 1985; Barr and Macdonald, 1987) and are followed later by K-rich intrusions (Thanasuthipitak, 1978).

(3) The Thai tuffs and tuffites described in this paper, when judged from the interbedded limestones, are closely associated with shallow-water deposits (Altermann, 1989). Either they were directly deposited on the shallow carbonate platform or redeposited into the deeper basin by turbidites from the platform.

Of importance for the following discussion, is the fact that the warm-water corals from Sumatra (Fontaine, 1986) are associated with tuffs in similar sedimentary facies as described above for central Thailand. Furthermore, Metcalfe (1986) suggested an analogue island-arc development for eastern Malaysia ("Manabor Block").

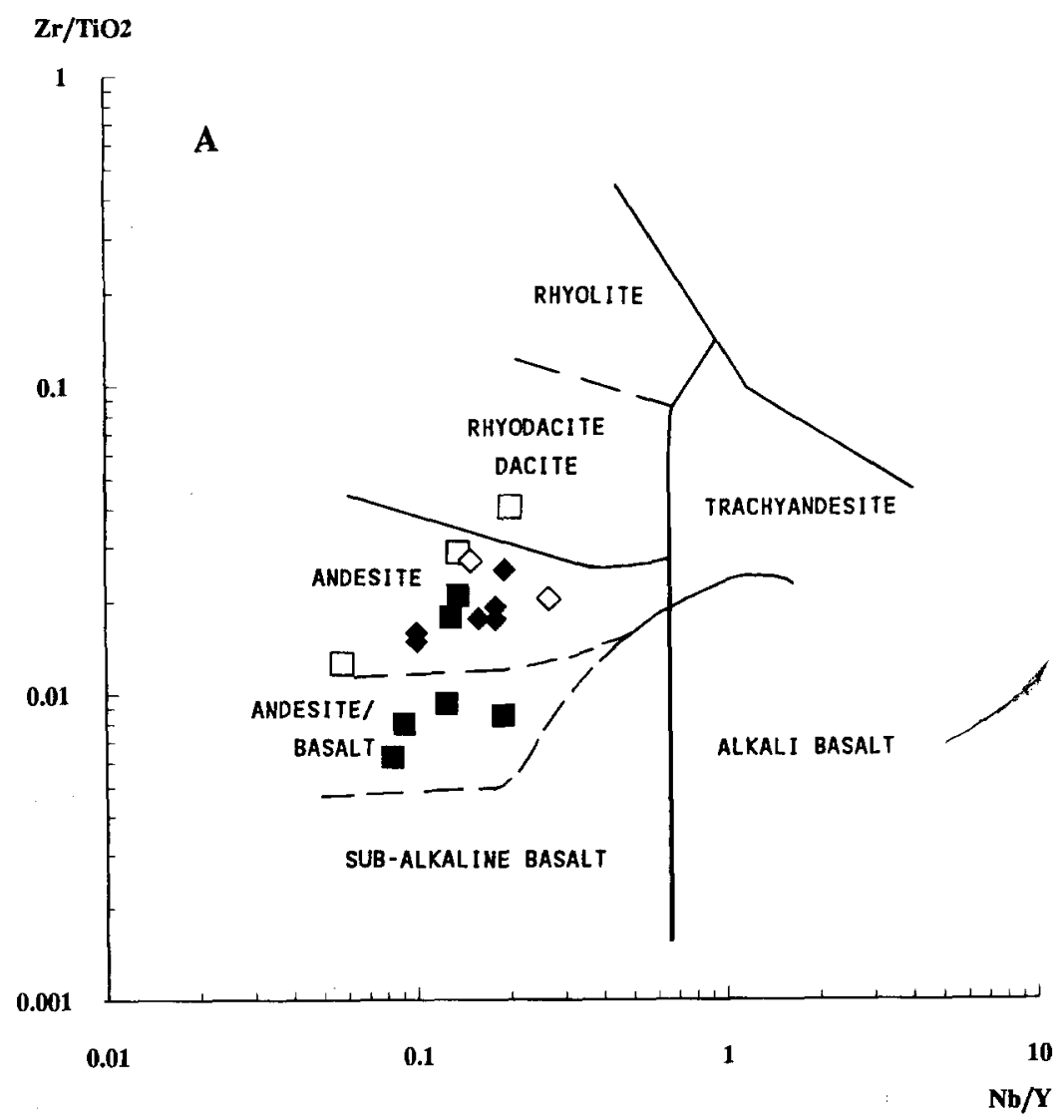

Fig. 3A-C. Classification of the Permo-Carboniferous volcanic rocks of central Thailand using immobile elements (Winchester and Floyd, 1977). For symbols see Fig. 2. 
Burton (1986) refered to reports on Upper Carboniferous to Middle Permian fossiliferous, tuffaceous sandstones and rhyolitic tuffs from the upper part of his Phuket Group. These occurrences are located east of the main (northern peninsula) outcrops of the pebbly mudstones. He suggested, that the Phuket Group was deposited west of a Late Carboniferous volcanic arc.

Altermann (1986), following Helmcke (1985) described the palaeogeography of mainland Southeast Asia as being formed during a collision of the part of Palaeoeurasia (Indosinia) with a volcanic arc (Fig. 9). In this interpretation the sedimentary basin, folded and overthrust to form the Petchabun Fold and Thrust Belt, represents a back-arc basin floored by thinned continental crust. This basin separated the "Indosinia Craton" at present east from the volcanic arc or arcs on the "Shan Thai
Craton" in the west. The Petchabun back-arc sedimentary basin was closed in the Middle Permian by a westward-directed subduction as indicated by the vergence of the isoclinal folding (Helmcke, 1983), while the main, eastwarddirected, B-subduction zone was located farther to the west. The volcanic activity subsided in Murgabian (uppermost Middle Permian) times with the onset of the folding in the back-arc basin.

In this interpretation, the Nan-Uttaradit rocks (Barr and Macdonald, 1987) possibly represent an immature and earlier volcanic arc attached during an older Variscan episode, as is suggested by the age of $269 \pm 12 \mathrm{Ma}$ of the crossite schists. Furthermore, the same explanation can be applied to the Devono-Carboniferous age of metamorphism of the mafic rocks from the Nan-Uttaradit Belt (Dam and Helmcke, 1985).

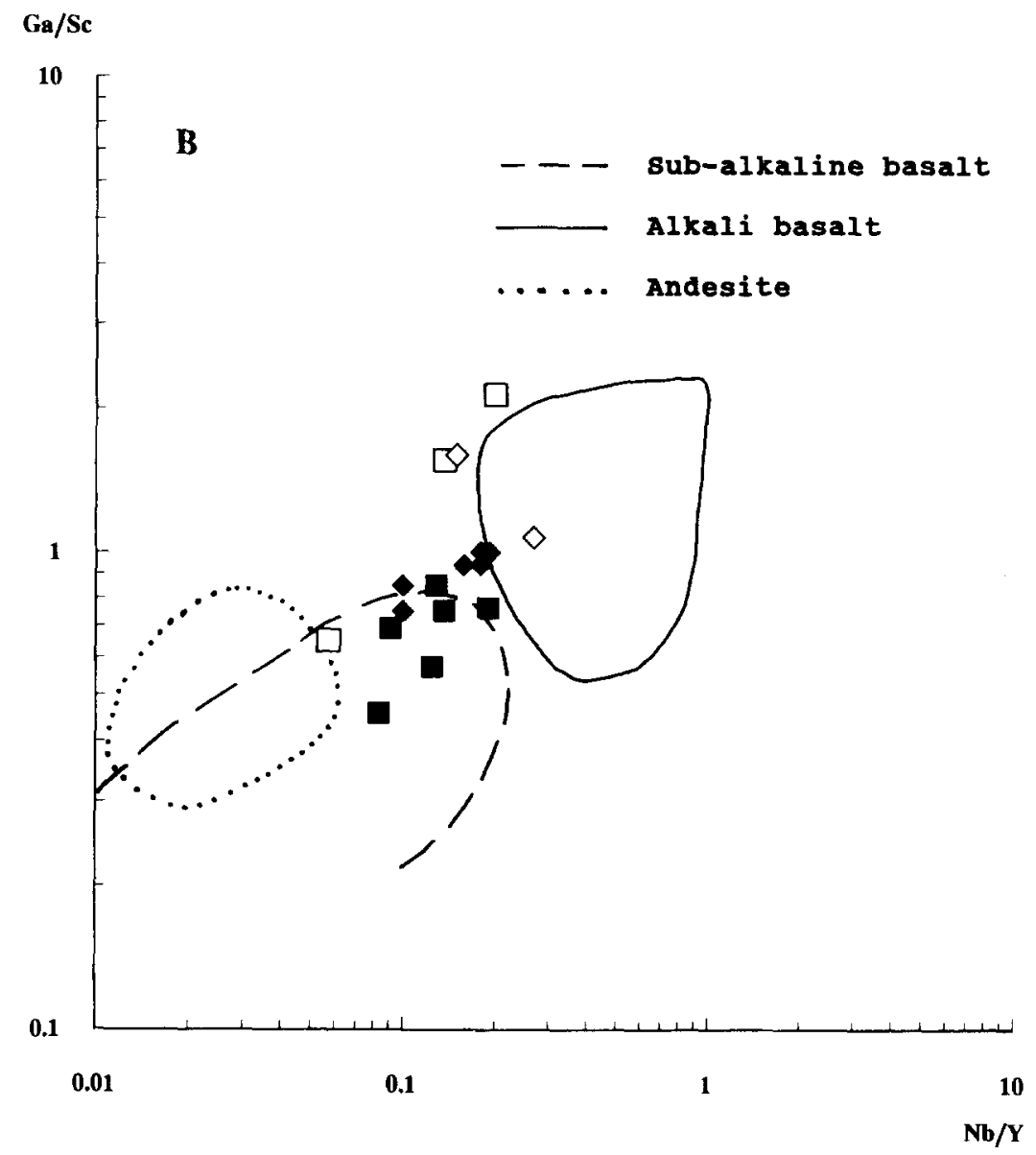

Fig. 3B. 


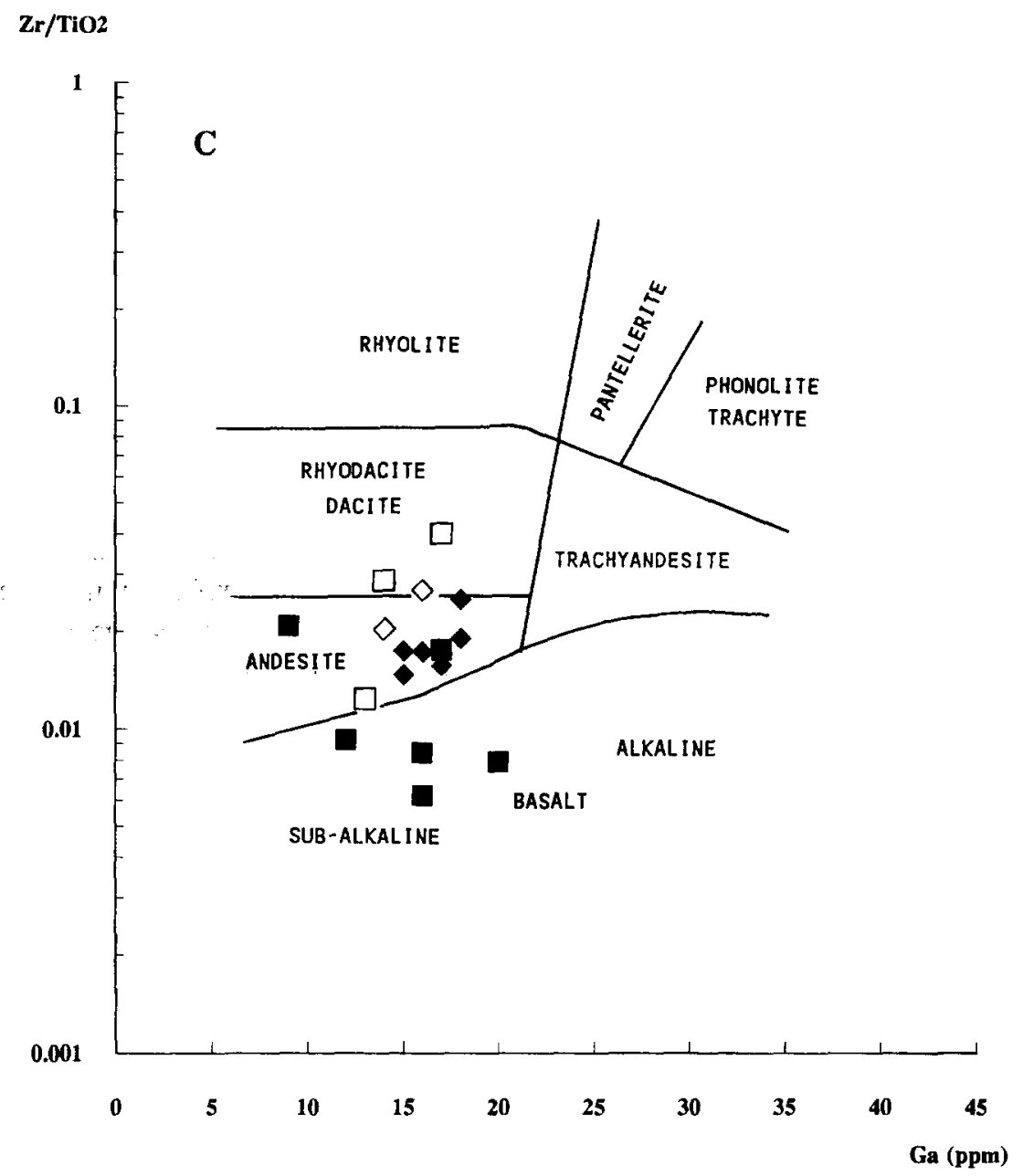

Fig. 3C. For explanation see p. 202.

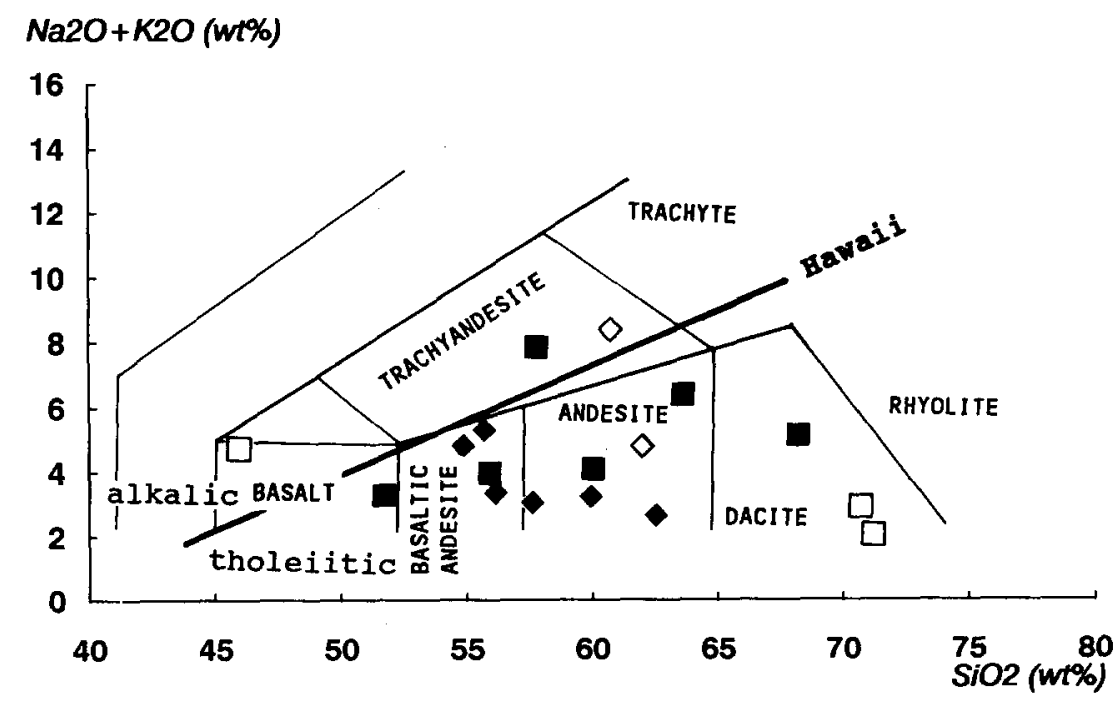

Fig. 4. Central Thailand's Permo-Carboniferous volcanic rocks plotted in the TAS diagram (Zanettin, 1984). For symbols see Fig. 2. 


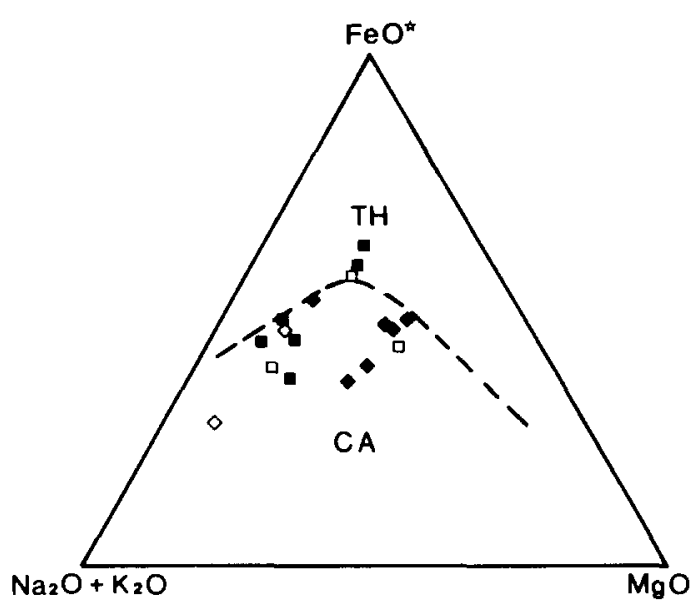

Fig. 5. Central Thailand's Permo-Carboniferous volcanic rocks plotted in the AFM diagram (Miyashiro, 1974). $\mathrm{FeO}^{*}=\mathrm{Fe}_{2} \mathrm{O}_{3}$ $+0.9 \mathrm{FeO}$. For symbols see Fig. 2.

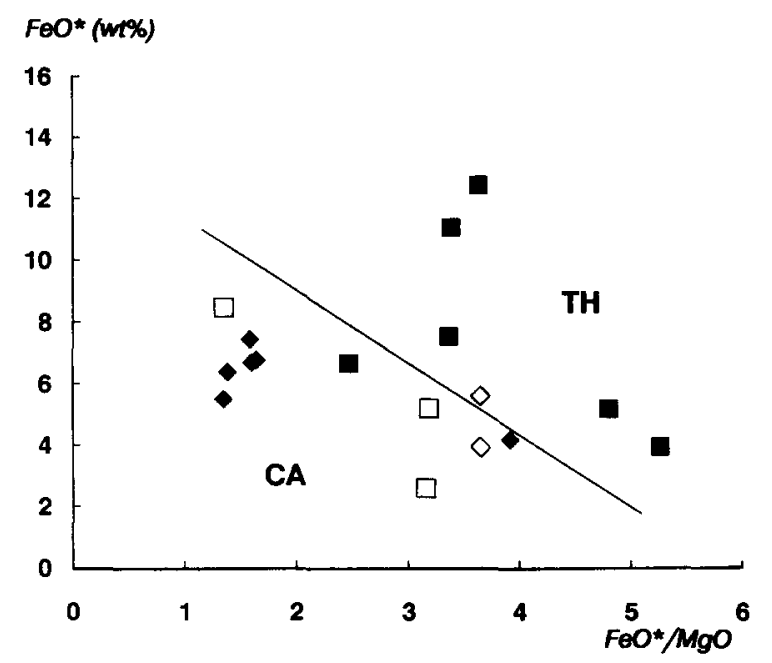

Fig. 6. Central Thailand's Permo-Carboniferous volcanic rocks plotted in the $\mathrm{FeO}^{*}-\mathrm{FeO}^{*} / \mathrm{MgO}$ diagram. $\mathrm{FeO}^{*}=\mathrm{Fe}_{2} \mathrm{O}_{3}+0.9$ FeO. For symbols see Fig. 2.

In this case the Palaeozoic geology of Southeast Asia would be the result of an interaction of Benioff (B) and Ampferer (A) subduction zones and of the repeated attachment of volcanic arcs to the eastward-lying continental mass by birth and destruction of back-arc basins. These volcanic arcs could consist of inner and outer arcs with varying geochemistry depending on their distance from the subduction zone and their relative maturity, very much like the situation in Japan today.

Figure 9 depicts this model in five steps:
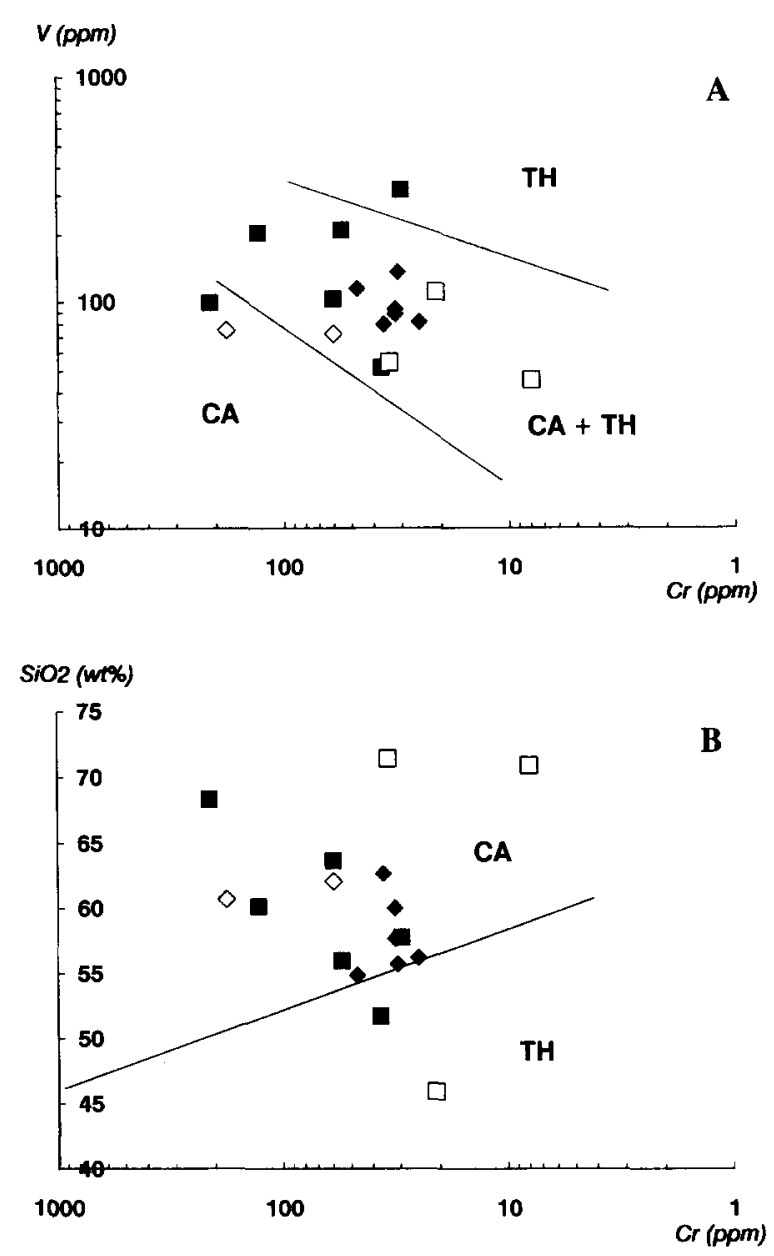

Fig. 7. Central Thailand's Permo-Carboniferous volcanic rocks plotted in the $\mathrm{V}-\mathrm{Cr}$ and $\mathrm{SiO}_{2}-\mathrm{Cr}$ diagrams (Miyashiro and Shido, 1975). For symbols see Fig. 2.

(1) At the Devonian/Carboniferous boundary the type II ophiolites of Beccaluva et al., 1979 (Barr and Macdonald, 1987) were obducted during the Shan Thai-Indosinia collision, as indicated by the $344 \pm 22 \mathrm{Ma} \mathrm{K} /$ Ar-age (Helmcke, 1985). On the western edge of Shan Thai the sedimentation of pebbly mudstones on a continental margin was triggered by the collisional folding and uplift (Altermann, 1986).

(2) During the Carboniferous to Early Permian, spreading processes led to the development of a volcanic arc or arcs and of back-arc basins. The spreading was probably caused by a lower convergence rate and steeper angle of the eastward subduction beneath the Shan Thai Block. In the 


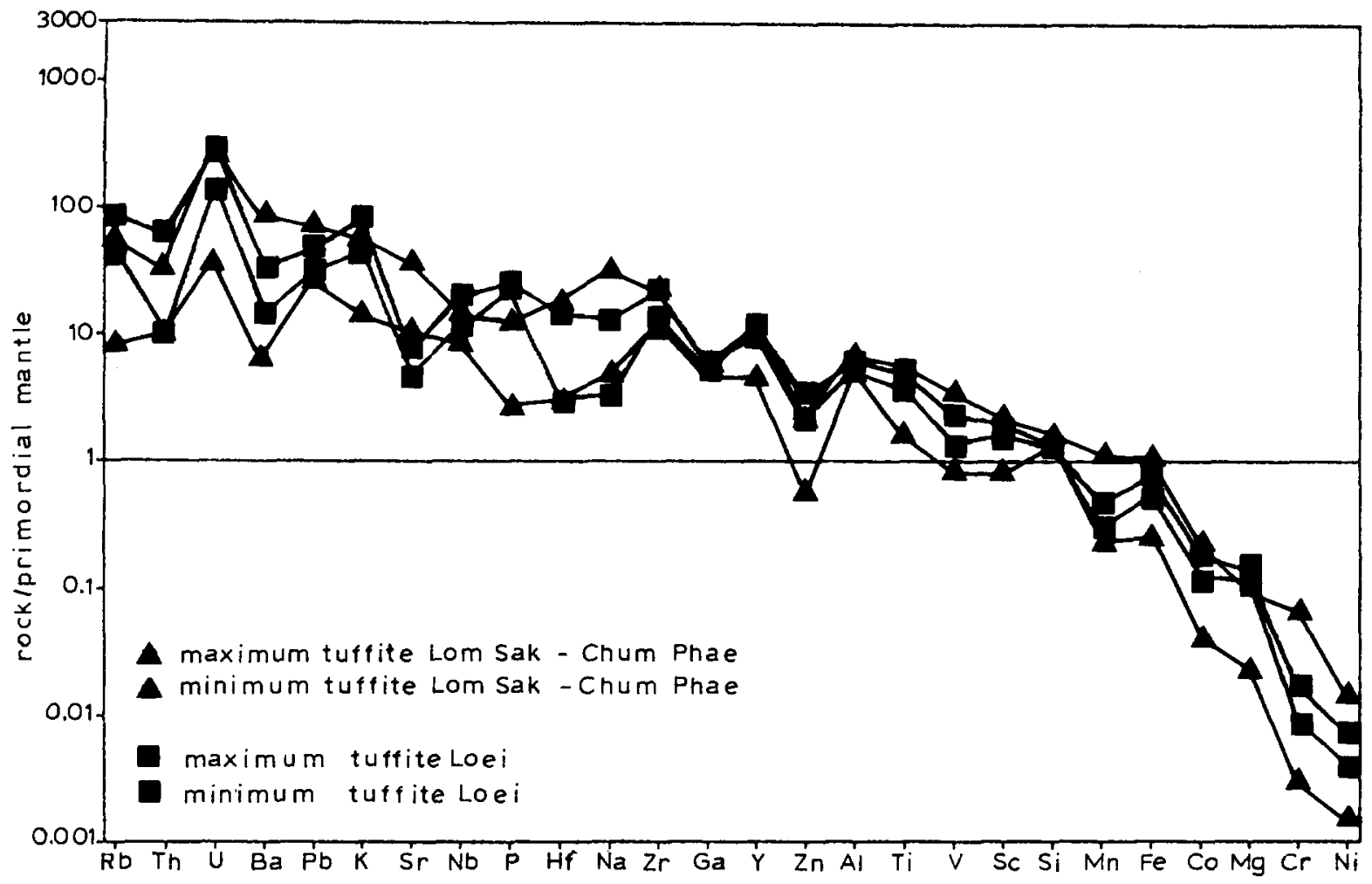

Fig. 8. Central Thailand's Permo-Carboniferous volcanic rocks normalized to primordial mantle (Schermerhorn, pers. comm.). The enrichment of incompatible elements and the depletion of the compatible elements suggest continental magma provenance.

Petchabun region, a pelagic basin developed, which received occasional sedimentation of turbiditic limestones and tuffites from the neighboring platforms and arc. The deposition of pebbly mudstones on the western edge of Shan Thai came to an end in Early Permian and was followed by Lower Permian carbonates.

(3) In the Early to Middle Permian, the onset of westward A-subduction in the back-arc basin led to flysch sedimentation and folding in the Petchabun basin and to the final closure of the back-arc sea (Helmcke, 1983, 1985). The volcanism turned more calc-alkalic and eventually subsided approximately with the Murgabian folding. Crossite schists developed in the reactivated Nan-Uttaradit suture $(269 \pm 12 \mathrm{Ma}$; Barr and Macdonald, 1987). The A-subduction was probably caused by increased convergence rate and shallower subduction angle. The flat subduction angle supported the intrusion of the Permo-Triassic "eastern range" granites of I-type, but with significant crustal component (Cobbing et al., 1986).

(4) In Late Permian to Early Triassic time, mainly uplift and erosion occurred. Sedimentation took place in marginal marine and intermontane basins. In the Triassic, post-collisional S-type granites intruded the "main range" (Cobbing et al., 1986).

(5) In the Late Triassic, continental half-graben basins in the east and marine basins in the west developed over the Shan Thai and Indosinia realms. The subsidence was caused by extensional collapse of the overthickened crust (Cooper et al., 1989).

\section{Conclusions}

The geotectonic frame of Thailand can be explained in a model of repeated accretion of volcanic arcs by the Late Palaeozoic subduction zone along the northern Tethys margin. The development of volcanic arcs and the opening and 


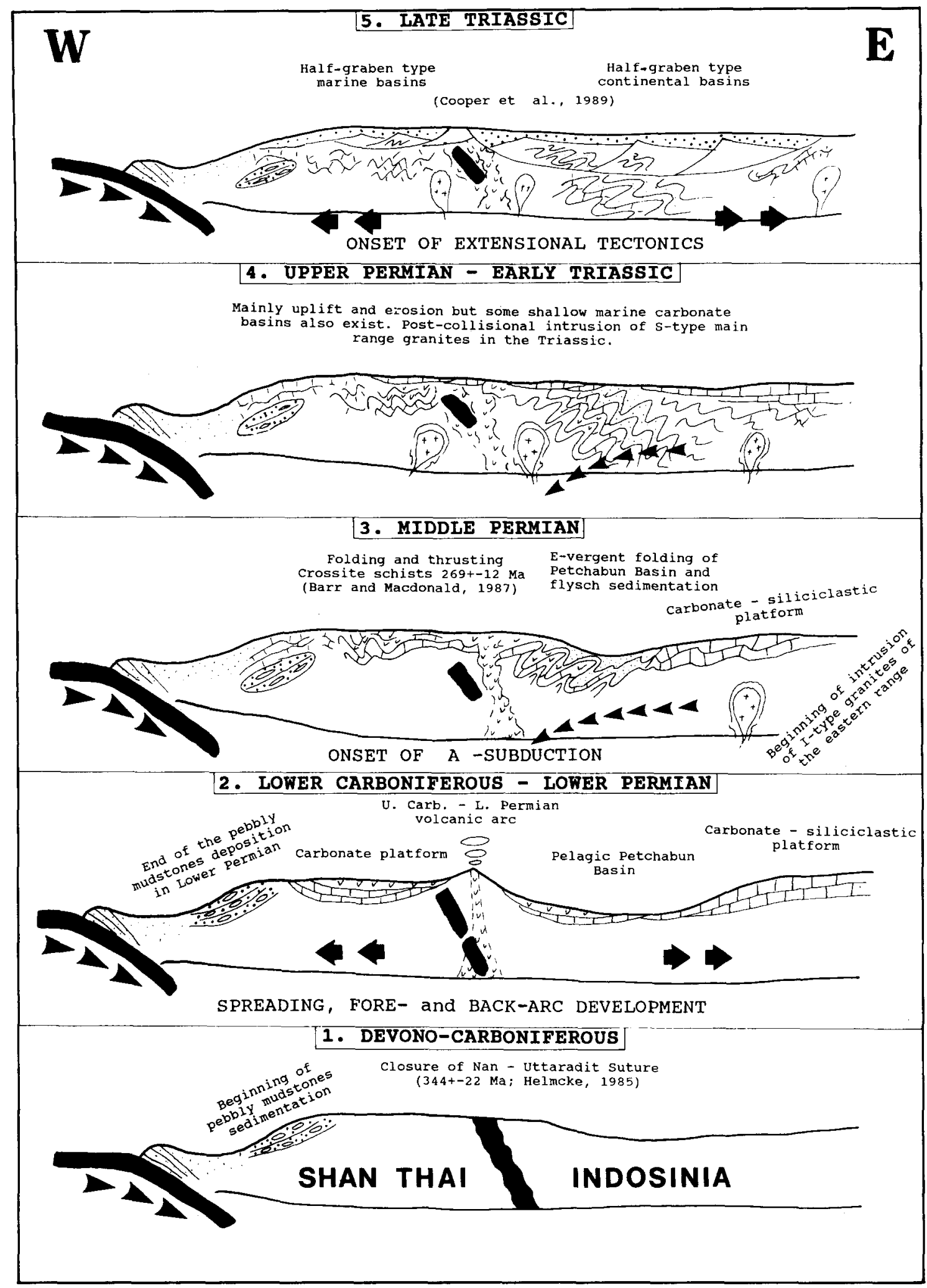

Fig. 9. Interpretation of the plate tectonic history of Southeast Asia in a W-E profile. For detailed explanation see text. 
closing of fore-arc and back-arc basins was probably controlled by the interaction of Benioff (B) and Ampferer (A) subduction zones.

Although hypothetical, this interpretation offers some advantages:

This concept agrees well with most of the field data known from Thailand and Malaysia. It accommodates explanation of the tectonic overprint of the region and the geometry of folds in the Petchabun Fold and Thrust Belt. It fits with the regional sedimentary cycles and the relative sea-level changes, and the sedimentation of the Southeast Asian pebbly mudstone belt as discussed by Altermann (1989). Furthermore, it explains the occurrence of different volcanic belts and sutures in the region and the different metamorphic ages found in northern Thailand. It is also in agreement with the three granite provinces in Southeast Asia, as discussed by Cobbing et al. (1986), especially when taking into account that the subduction process along the northern Tethys margin continued also in the Mesozoic and Cenozoic. The location of the I-type granites in the east (PermoTriassic eastern range) and S-type granites in the west (Triassic main range) would be difficult to explain by a westward subduction. The I- and S-type tin granites of the western range are Cretaceous and Tertiary and thus, related rather to the destruction of the "Neotethys" and the flight of the Indian plate towards the north. Last but not least, it also allows the existence and closure of Mesozoic remnant seas as the Lampang basin in northern Thailand.

If the model proposed is correct, the dip direction of the main (B) subduction zone has not changed since Palaeozoic to Recent times, taking the Cenozoic clockwise rotation of Southeast Asia into account.

The model presented does not discuss the Early Palaeozoic position of the "Shan Thai Craton". A pre-Devonian Gondwana provenance of this part of Southeast Asia might be possible. More data are needed to support the idea.

\section{Acknowledgements}

The author would like to express his sincere thanks to R. Winkel for granting access to his samples (all Ru-samples); to Prof. D. Helmcke, University Göttingen, and Prof. L.J.G. Schermerhorn, FU-Berlin, for the many criticisms and helpful discussions. Prof. Schermerhorn also helped with the XRF-analyses. Warmly acknowledged is the contribution of Dr. R. Ingavat-Helmcke, DMR-Bangkok, who carried out the palaeontological investigations.

\section{References}

Altermann, W., 1986. The Upper Palaeozoic pebbly mudstone facies of Peninsular Thailand and Western Malaysia-Continental margin deposits of Palaeoeurasia. Geol. Rundsch., 75(2): 79-89.

Altermann, W., 1987. The Permo-Carboniferous facies development in Thailand: A plate tectonic discussion. In: 11 th Int. Carboniferous Congr., Beijing, in press.

Altermann, W., 1989. Facies development in the Permian Petchabun Basin, central Thailand. VWB, Berlin, 155 pp.

Amstutz, G.E., 1974. Spilites and spilitic rocks (UGS Ser. A, 4). Springer, Berlin, $482 \mathrm{pp}$.

Barr, S.M. and Macdonald, A.S., 1987. Nan River suture zone, northern Thailand. Geology, 15: 907-910.

Barr, S.M., Tantisukrit, C., Yaowanoiyothin, W. and Macdonald, A.S., 1985. Petrography and geochemistry of volcanic rocks in the San Kamphaeng area, Northern Thailand. GST Newsl., (2582), 17/5-6:24.

Baum, F., Von Braun, E., Hahn, L., Hess, A., Koch, K.-E., Kruse, G., Quarch, H. and Siebenhüner, M., 1970. On the geology of Northern Thailand. Beih. Geol. Jahrb., 102, $23 \mathrm{pp}$.

Beccaluva, L., Piccardo, G.B. and Serri, G., 1979. Petrology of northern Apennine ophiolites, and comparison with other Tethyan ophiolites. Ofioliti, 4: 43-66.

Buffetaut, E. and Ingavat, R., 1985. The Mesozoic vertebrates of Thailand. Sci. Am., 253(2): 80-87.

Bunopas, S. and Vella, P., 1978. The Late Palaeozoic and Mesozoic structural evolution of Northern Thailand-a plate tectonic model. In: P. Nutalaya (Editor), Proc. GEOSEA III, Bangkok, 1978, pp. 133-140.

Bunopas, S. and Vella, P., 1984. Phuket-Kaeng Krachang Groups, a rifted continental margin deposits with effect on icerafting megaclasts from Gondwana. In: Abstr. GEOSEA V, 9-14 April 1984, Kuala Lumpur.

Bunopas, S., 1981. Palaeogeographic history of western Thailand and adjacent parts of South-East Asia; A plate tectonic interpretation. Geol. Surv. Dev., DMR, Bangkok, Geol. Surv. Pap., 5, 810 pp.

Burret, C. and Stait, B., 1986. South East Asia as a part of an early Palaeozoic Australian Gondwanaland. In: Proc. GEOSEA V, 1. Geol. Soc. Malaysia Bull., 19: 103-107.

Burton, C.K., 1986. The Kanchanaburi supergroup of Peninsular and Western Thailand. In: Proc. GEOSEA V , 2. Geol. Soc. Malaysia Bull., 20: 311-361.

Cobbing, E.J., Mallick, D.I.J., Pitfield, P.E.J. and Teoh, L.H., 
1986. The granites of Southeast Asian Tin Belt. J. Geol. Soc. London, 143: 537-550.

Cooper, M.A., Herbert, R. and Hill, G.S., 1989. The structural evolution of Triassic intermontane basins in northeastern Thailand. In: Int. Symp. on Intermontane Basins: Geology and Resources, Chiang Mai, pp. 231-242.

Damm, K.-W. and Helmcke, D., 1985. Arbeitsbericht zum Projekt: "Regionale Geologie, Petrologie, Geochemie und Geochronologie der Ultrabasite/Basite und ihrer Rahmengesteine in Nord Thailand", Rep. DFG. 27 pp.(unpublished).

De Witt, M., Jeffery, M., Bergh, $H$. and Nicolaysen, L., 1988. Geological Map of Gondwana. AAPG, Univ. Witwatersrand.

Dickins, J.M., 1985. Palaeobiofacies and palaeobiogeography of Gondwanaland from Permian to Triassic. In: K. Nakawara and J.M. Dickins (Editors), The Tethys. Tokai Univ. Press, Tokyo, pp. 83-92.

ESCAP, 1988. Stratigraphic correlation between sedimentary basins of the ESCAP region. 13. In: ESCAP Atlas of Stratigraphy, 7: Triassic of Asia, Australia and the Pacific (Miner. Resour. Dev. Ser., 56). IGCP, UN, New York.

Fontaine, H., 1986. Discovery of Lower Permian corals in Sumatra. In: Proc. GEOSEA V, 1. Geol. Soc. Malaysia Bull., 19: 183-191

Garson, M.S., Young, B., Mitchell, A.H.G. and Tait, B.A.R., 1975. The geology of the tin belt in Peninsula Thailand around Phuket, Phang Nga and Takua Pa. Overseas Mem. IGS, 1.

Gatinsky, Y.G. and Hutchinson, C.S., 1984. Cathaysia, Gondwanaland, and the Palaeotethys in the evolution of continental S.E. Asia. In: Abstr. GEOSEA V, 9-14 April 1984, Kuala Lumpur, pp. 11-12.

Grant, R.E., 1976. Permian brachiopods from southern Thailand. J. Palaeontol., 50(2), $269 \mathrm{pp}$.

Hahn, L., 1976. The stratigraphy and palaeogeography of the non-marine Mesozoic deposits in Northern Thailand. Geol. Jahrb. B, 21: 155-169.

Haile, N.S., 1980. Palaeomagnetic evidence from the Ordovician and Silurian of northwest Peninsular Malaysia. Earth. Planet. Sci. Lett., 48: 233-236.

Helmcke, D., 1983. On the Variscan evolution of central Mainland Southeast Asia. Earth Evol. Sci., 4: 309-319.

Helmcke, D., 1985. The Permo-Triassic "Palaeotethys" in Mainland Southeast Asia and adjacent parts of China. Geol. Rundsch., 74(2): 215-228.

Helmcke, D., 1986. Die Alpiden und die Kimmeriden: Die verdoppelte Geschichte der Tethys-Discussion. Geol. Rundsch., 75(2): 495-499.

Ingavat-Helmcke, R. and Helmcke, D., 1986. Permian fusulinacean faunas of Thailand-event correlated evolution. In: O.H. Walliser (Editor), Global Bio-events (Lecture Notes Earth Sci., 8). Springer, Berlin, pp. 241-248.

Macdonald, A.S. and Barr, S.M., 1978. Tectonic significance of a Late Carboniferous volcanic arc in Northern Thailand. In: P. Nutalaya (Editor), Proc. GEOSEA III, Bangkok, 1978, pp. 151-156.

Macdonald, A.S. and Barr, S.M., 1984. The Nan River maficultramafic belt, Northern Thailand: Geochemistry and tectonic signification. Geol. Soc. Malaysia Bull., 17: 209-224.

Macdonald, A.S., Barr, S.M., Yaowanoiyothin, W. and Panja- sawatwong, Y., 1985. Blue schist-mafic-ultramafic complexes of the Nan River Belt, Northern Thailand. GST Newsl., 17(5-6), p.25.

Macdonald, G.A. and Katsura, T., 1964. Chemical composition of Hawaii lavas. J. Petrol., 5: 82-133.

McElhinny, M.W., Haile, N.S. and Crawford, A.R., 1974. Palaeomagnetic evidence shows Malaya Peninsula was not a part of Gondwanaland. Nature, 252: 641-645.

Metcalfe, I., 1983. Southeast Asia. In: C.F. Winkler-Prins and C.F. Granados (Editors), The Carboniferous of the World. 1. I.U.G.S. Publ., 16: 213-243.

Metcalfe, I., 1986. Late Palaeozoic palaeogeography of Southeast Asia: some stratigraphical, palaeontological and palaeomagnetic constrains. In: Proc. GEOSEA V, 1. Geol. Soc. Malaysia Bull., 19: 153-164.

Metcalfe, I., 1989. Triassic sedimentation in Peninsular Malaysia: Palaeotectonic implications. In: Abstr. 28th IGC, Washington, DC, July 9-19 1989, 2, pp. 416-417.

Mitchell, A.H.G., 1977. Tectonic settings for emplacement of Southeast Asian tin granites. Bull. Geol. Soc. Malaysia, 9: $123-140$.

Miyashiro, A., 1974. Volcanic rock series in island arcs and active continental margins. Am. J. Sci., 274: 321-355.

Miyashiro, A. and Shido, F., 1975. Tholeiitic and calc-alkaline series in relation to the behaviours of titanium, vanadium, chromium, and nickel. Am. J. Sci., 275: 265-267.

Rao, C.P., 1988. Palaeoclimate of some Permo-Triassic carbonates of Malaysia. Sediment. Geol., 60: 163-171.

Schermerhorn, L.J.G., 1973. What is keratophyre? Lithos, 6: $1-11$,

Sengör, C.A.M., 1985. Die Alpiden und die Kimmeriden: Die verdoppelte Geschichte der Tethys. Geol. Rundsch., 74(2): 181-213.

Shervais, J.W., 1982. Ti-V plots and the petrogenesis of modern ophiolitic lavas. Earth Planet. Sci. Lett., 59: 101-118.

Stauffer, P.H., 1983. Unraveling the mosaic of Palaeozoic crustal blocks in Southeast Asia. Geol. Rundsch., 72(3): 1061-1080.

Stauffer, P.H. and Lee, C.P., 1986. Late Palaeozoic glacialmarine facies in Southeast Asia and its implications. In: Proc. GEOSEA V, 2. Geol. Soc. Malaysia Bull., 20: 363-397.

Stauffer, P.H. and Lee, C.P., 1987. The Upper Palaeozoic pebbly mudstone facies of peninsular Thailand and western Malaysia-Continental margin deposits of PalaeoeurasiaDiscussion. Geol. Rundsch., 76(3): 945-948.

Stöcklin, J., 1984. The Tethys paradox in the plate tectonics. In: Plate Reconstructions from Palaeozoic Palaeomagnetism, Geodyn. Ser., 12: 27-28.

Thanasuthipitak, T., 1978. A review of igneous rocks of Thailand. In: P. Nutalaya (Editor), Proc. GEOSEA III, Bangkok, 1978, pp. 775-782.

Tozer, E.T., 1989. Tethys, Thetis, Thethys or Thetys? What, where, and when was it? Geology, 17: 882-884.

Waterhouse, J.B., 1982. An Early Permian cool-water fauna from pebbly mudstones in South Thailand. Geol. Mag., 119(4): 337-432.

Wielchowsky, C.C. and Young, J.D., 1985. Regional facies variations in Permian rocks of the Phetchabun Fold and Thrust Belt, Thailand. Proc. Symp. Stratigraphy, Dep. Miner. Resour., Bangkok, pp. 41-55. 
Winchester, J.A. and Floyd, P.A., 1977. Geochemical discrimination of different magma series and their differentiation products using immobile elements. Chem. Geol., 20: 325-343.

Winkel, R., Ingavat, R. and Helmcke, D., 1983. Facies and stratigraphy of the Lower-lower Middle Permian strata of the Petchabun Fold and Thrust Belt in central Thailand. In: Workshop Stratigr. Correlation Thailand and Malaysia, 1, Had Yai, Thailand, September 1983, pp. 293-306.
Wood, D.A., 1980. The application of a Th-Hf-Ta diagram to problems of tectonomagmatic classification and to establishing the nature of crustal contamination of basaltic lavas of the British Tertiary Volcanic Province. Earth Planet. Sci. Lett., 50: 11-30.

Zanettin, B., 1984. Proposed new chemical classification of volcanic rocks. Episodes 7(4): 19-20. 